\title{
Analysis on the Impact of Short-Term International Capital Flows on Chinese Stock Market on the Basis of VAR Model
}

\author{
Ning $\mathrm{Wu}^{1}$ \\ ${ }^{1}$ School of Economics and Management, Nanjing University of Aeronautics and Astronautics, Nanjing, China \\ Correspondence: Ning Wu, School of Economics and Management, Nanjing University of Aeronautics and \\ Astronautics, Nanjing, Jiangsu Province, China. Tel: 199-5144-2060. E-mail: shhswn@163.com
}

Received: June 2, 2018

Accepted: June 22, 2018

Online Published: July 5, 2018

doi:10.5539/ijef.v10n8p77

URL: https://doi.org/10.5539/ijef.v10n8p77

\begin{abstract}
With the continuous development of global economic integration and financial markets, international capital flows more and more frequently, the frequent flow of international capital will inevitably affect the yield of Chinese stock market. This article uses short-term international capital inflows SS and Shanghai composite index R as research objects. Based on monthly data from January 2002 to October 2017, VAR model was constructed using Eviews 8.0 to study the impact of short-term international capital flows on Chinese stock market. Empirical studies have found that short-term international capital flow is the granger cause of changes in the Shanghai composite index yield, while the yield of Chinese stock market will not affect short-term international capital flows. At the end of this paper, relevant suggestions are put forward according to the conclusions.
\end{abstract}

Keywords: short-term international capital, Chinese stock market, the VAR model

\section{Introduction and Literature Review}

In the 1990s, the main reason for the outbreak of financial crisis in emerging economies was the large-scale frequent flow of short-term international capital. The rapid flow of international capital will have a major impact on the financial stability of emerging market countries, negatively affecting a country's consumption, investment, and economic output. If it does not adopt certain policy measures, it will eventually evolve into a crisis. With the continuous development of economic globalization, emerging market countries have continuously expanded their capital projects. The 'Thirteenth Five-Year Plan' issued by the State Council emphasizes the need to achieve orderly conversion of capital projects. In addition, in 2015, the International Monetary Fund announced that the RMB will join the SDR. These conditions have played a catalytic role in the liberalization of capital projects. The accelerated liberalization of capital projects will inevitably lead to the frequent flow of international capital and encourage fluctuations in the return rate of the stock market. Besides, China has continuously introduced relevant financial system policies, such as QFII for Qualified Foreign Institutional Investors, QDII for Qualified Domestic Institutional Investors, and Shanghai-Hong Kong Stock Connect. The introduction of these mechanisms has facilitated short-term international capital flows. However, what we cannot ignore is that China is undergoing a period of economic structural transformation and the economic growth rate continues to slow. At the same time, the Federal Reserve keeps increasing its rate hike expectations and expectations of RMB appreciation continue to weaken. Therefore, a part of the short-term international capital with the main purpose of speculative arbitrage is quickly flowing out. The large-scale flow of short-term international capital then has an impact on domestic asset prices and their yields. The purpose of this paper is to examine the impact of international capital flows on Chinese stock market and make corresponding recommendations.

The process of economic globalization and financial integration continues to deepen. Many scholars at home and abroad have conducted theoretical and empirical studies on the economic effects of short-term international capital, the impact on capital markets, and the impact on housing prices. From the perspective of foreign research, Kim and Yang (2009) based on panel data, through empirical analysis, concluded that for Asian countries, short-term international capital inflows will not have a significant impact on domestic asset price changes. However, short-term international capital inflows will cause domestic asset prices to rise. Olaberrla (2012) used panel data from 40 countries between 1990 and 2010 to study capital inflows and domestic asset prices. Through empirical analysis and research, it is found that when large-scale capital inflows exist, the asset 
prices of emerging economies have an upward trend.

Judging from domestic research, Yihao and Xiaohua (2008) found that there was a correlation between changes in stock prices and hot money based on the analysis of the CLR model. The upward movement of stock prices would cause the influx of hot money, and at the same time, the inflow of hot money would promote the stock price to go up. When Yanbing (2013) studied the relationship between short-term international capital flows and stock prices, it was found that compared with the Shanghai composite index, the SME board index was the main cause of short-term international capital inflows. According to the TVP-SV-VAR model and based on the monthly data from January 2002 to March 2014, Lihua and Guangmin (2014) found through empirical analysis that the relationship between short-term international capital flows and stock prices presented different results over time, that is, the relationship between them was different under different research backgrounds. Haizhen (2015) has applied the multiple regression model to find that short-term international fund flow will have a positive effect on the current period yield of the Chinese stock market. According to the 'price pressure' hypothesis, in the short term, there will have an impact. From the perspective of the stock market segment, the most international funding of financial sectors, the health care sector and the information technology board also attract a lot of inflow of international funds.

At present, most scholars use panel data empirical research to analyze the impact of short-term international capital flows on the economic output and investment effects of emerging market countries. However, there are few empirical studies on the impact of Chinese short-term international capital flows on the stock market. According to theoretical analysis, it can be concluded that short-term international capital flows will affect the stock market. This paper will conduct empirical research on the basis of theoretical analysis. Therefore, this article studies the short-term international capital flow and the Shanghai composite index yield. A VAR model was established based on the stability of two time series, followed by granger test, impulse response function analysis, and variance decomposition. Then study and analyze the impact of short-term international capital flows on Chinese stock market.

\section{Description and Analysis of Short-Term International Capital Flows and Chinese Stock Market}

\subsection{The Concept and Measurement of Short-term International Capital Flow}

International capital flows are the flow of capital from a country whose residents offering loans to other people, or the capital that is triggered by the purchase of property. According to the International Monetary Fund's regulations, borrowings or investments with a term of less than one year are called short-term capital. Different scholars have different methods for measuring the size of short-term international capital flows. At present, there are two main methods of measurement: direct method and indirect method. However, most of these two methods measure international short-term capital flows in-year unit. In 2006, China National Bureau of Statistics measures the short-term flow of international capital based on the indirect measurement of short-term international capital flows and uses the three-factor indirect assessment method according to Chinese specific conditions. The formula is 'short-term international capital inflows $=$ foreign exchange reserves increment - trade surplus - foreign direct investment FDI'. Based on the availability of data, this paper decides to use the three-factor indirect assessment method to measure short-term international capital inflows. This article measures the amount of short-term international capital inflows from January 2002 to October 2017. The original foreign exchange reserves, trade surpluses, and foreign direct investment FDI data are all derived from the Wind database.

\subsection{Analysis of Chinese Stock Market}

For most investors, the stock market is the first market to consider. At the same time, the return on the stock market is significantly affected by international capital, especially hot money. When investors find profitable, they will invest a lot of capital, which will bring about large fluctuations in the stock market. After they get a lot of income, they will choose to withdraw funds quickly, which exacerbates the large fluctuations in the stock market. Considering that most domestic investors tend to judge the stock market through the Shanghai composite index, this paper selects the Shanghai composite index as the research object and the original data comes from the Wind database.

Figure 1 shows the volatility trend of the Shanghai composite index yield over the period from 2002 to 2017. It can be seen that the volatility of the Shanghai composite index yield is relatively small from 2002 to 2007 . Affected by the financial crisis, the yield of the Shanghai composite index continued to be negative from 2008 to 2009. From 2010 to 2014, the global economy was in a recovery phase, and the economic efficiency of enterprises also tends to improve. The yield of the Shanghai composite index rose slightly. From 2015 to 2016, the Shanghai composite index yield rate fluctuates in the context of capital flight and economic bubble. In 2017, due to the influence of national economic policies, capital flows and investor sentiment, the Shanghai composite index yield tends to be 
flat.

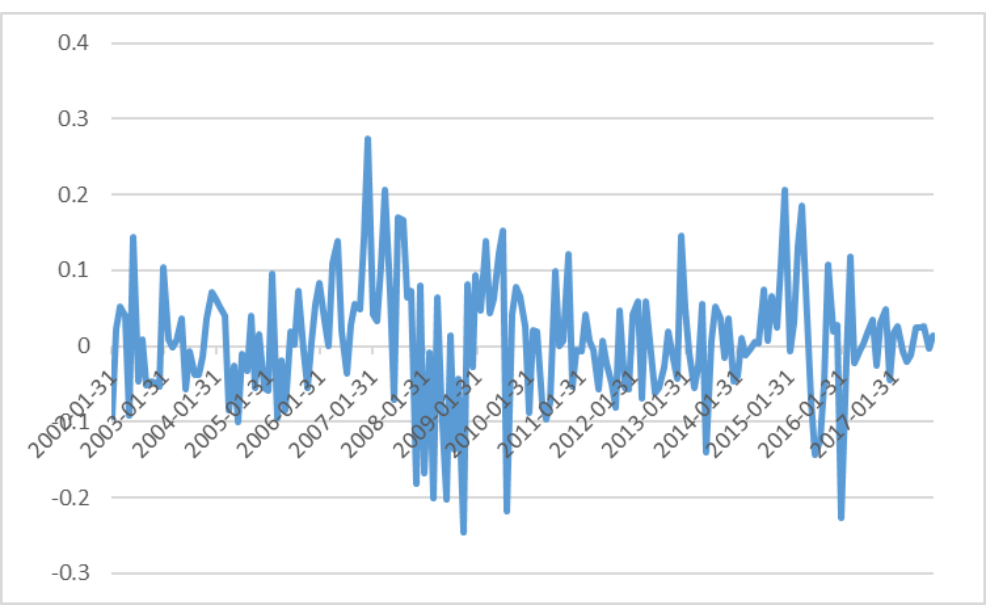

Figure 1. The Shanghai composite index return series during 2002-2017

\section{Empirical Analysis}

\subsection{Stationary Test}

This paper selects the monthly data of short-term international capital inflows and the Shanghai composite index yield from January 2002 to October 2017, and conducts empirical research using Eviews8.0. Before using VAR model for analysis, it is necessary to test the stationarity of time series data. In this paper, ADF unit root test method is adopted. The short-term international capital inflow is denoted as SS, the Shanghai composite index monthly yield is denoted as R, and the unit root test results are shown in Table 1. From Table 1, it can be seen that the short-term capital inflow SS and the Shanghai composite index monthly yield R are stable at the significance level of $1 \%$. Therefore, the VAR model of short-term international capital flow SS and the Shanghai composite index yield $\mathrm{R}$ can be constructed.

Table 1. Stationary test for roots of unity of each variable

\begin{tabular}{cccc}
\hline Variable & ADF statistics & Prob & Conclusion \\
\hline SS & -6.592741 & 0.0000 & stable \\
R & -12.10307 & 0.0000 & stable \\
\hline
\end{tabular}

Before establishing a VAR model, the optimal lag period needs to be determined. VAR model was established directly based on the default lag of Eviews8.0, and then the lag period was selected according to the optimal lag period criteria (LR, FPE, AIC, SC, HQ). Table 2 outputs the values of LR, FPE, AIC, SC and HQ in each lag period, with * denoted as the optimal lag period under this criterion selection. As shown in Table 2, the values of the five evaluation statistics can be seen, and three of the five evaluation indicators consider that a VAR(2) model should be established, so the establishment of the VAR(2) model is determined.

Table 2. Determining the optimal lag phase

\begin{tabular}{ccccccc}
\hline Lag & LogL & LR & FPE & AIC & SC & HQ \\
\hline 0 & -1183.009 & NA & 1550.489 & 13.02208 & 13.05729 & 13.03635 \\
1 & -1134.124 & 96.15816 & 946.8027 & 12.52884 & 12.63447 & 12.57166 \\
2 & -1121.071 & $25.39014^{*}$ & 857.1572 & 12.42935 & $12.60539^{*}$ & $12.50071^{*}$ \\
3 & -1116.396 & 8.989864 & 850.8663 & 12.42193 & 12.66840 & 12.52185 \\
4 & -1111.407 & 9.483565 & $841.7460^{*}$ & $12.41107^{*}$ & 12.72795 & 12.53953 \\
5 & -1109.698 & 3.211766 & 863.3202 & 12.43624 & 12.82354 & 12.59325 \\
6 & -1104.618 & 9.435179 & 853.2944 & 12.42437 & 12.88209 & 12.60992 \\
7 & -1101.496 & 5.729253 & 861.7937 & 12.43402 & 12.96215 & 12.64812 \\
8 & -1097.495 & 7.255052 & 862.0771 & 12.43401 & 13.03256 & 12.67665 \\
\hline
\end{tabular}

VAR Model Estimation Equation Results: 
$\mathrm{SS}=0.47 * \mathrm{SS}(-1)+0.26 * \mathrm{SS}(-2)-441.19 * \mathrm{R}(-1)-311.47 * \mathrm{R}(-2)-31.06$

$\mathrm{R}=0.000027 * \mathrm{SS}(-1)-0.000039 * \mathrm{SS}(-2)+0.09 * \mathrm{R}(-1)+0.16 * \mathrm{R}(-2)+0.004$

\subsection{Granger Causality Test}

The granger test is a special study to analyze whether there is a causal relationship between economic variables, that is, if variable $\mathrm{X}$ helps predict variable $\mathrm{Y}$, and variable $\mathrm{Y}$ helps predict variable $\mathrm{X}$. It is said that variable $\mathrm{X}$ is the granger cause of variable $\mathrm{Y}$, and variable $\mathrm{Y}$ is also the granger cause of variable $\mathrm{X}$. The granger test is very sensitive to reactions at different lag times, and different choices for the lag period can affect the results. According to the previous determination of the optimal lag period, the lag value of the granger test is taken as 2 . The test results are shown in Table 3. It can be seen that the $\mathrm{P}$ value of the original hypothesis that 'the Shanghai composite index yield $\mathrm{R}$ is not the granger cause of short-term international capital inflow SS' is 0.2380 .The original assumption cannot be rejected at the 5\% confidence level, that is, the Shanghai composite index yield $\mathrm{R}$ cannot affect the short-term international capital inflow SS. It was assumed that the P value of 'short-term international capital inflow SS is not the granger cause of the Shanghai composite index yield R' was 0.0464.Under the 5\% confidence level, the original hypothesis can be rejected, that is, the short-term international capital inflow SS is the granger cause of the Shanghai composite index yield R. From these two points, it can be concluded that the short-term international capital inflow SS has a direct impact on the Shanghai composite index yield R, while the Shanghai composite index yield $\mathrm{R}$ has no direct impact on the short-term international capital inflow SS.

Table 3. Granger causality test

\begin{tabular}{cccc}
\hline Null Hypothesis: & Obs & F-Statistic & Prob. \\
\hline R does not Granger Cause SS & 188 & 1.44685 & 0.2380 \\
SS does not Granger Cause R & & 3.12253 & 0.0464 \\
\hline
\end{tabular}

\subsection{Impulse Response Function Analysis}

The impulse response function analysis method is used to describe the response of an endogenous variable to the impact caused by the error term. That is, the degree of influence on the current value and future value of the endogenous variable after applying a standard deviation magnitude impact on the random error term.

The upper left corner of Figure 2 is the impulse response function graph of SS caused by the impact of SS. It can be seen that SS has a stronger positive response after receiving a positive impact in this period. Phase 1 to phase 2 showed a rapid decline, followed by a slow decline after phase 2, but it was always positive. The upper right corner of Figure 2 is an impulse response function graph of SS caused by the impact of R. It can be seen that for the impact of R, SS has a negative influence from the first period to the 10th period, but the impact is very small. It can be seen that the yield of the Shanghai composite index has little impact on short-term international capital flows.

The lower left corner of Figure 2 is the impulse response function graph of R caused by the impact of SS. It can be seen that for an impact on SS, R has a significant downward shock response in the first 3 phases. The response gradually weakens from the third period, and basically becomes 0 after the sixth period. It shows that the short-term international capital flows have certain influence on the rate of return of Chinese stock market. The lower right corner of Figure 2 is an impulse response function graph of R caused by the impact of R. For the impact of $\mathrm{R}, \mathrm{R}$ itself has a faster downward shock response in phase 1 . The response gradually weakens from the second period, and the response from the fourth period to the tenth period is basically zero. This indicates that the rate of return of Chinese stock market is largely related to its fluctuation in the last period. 
Response to Cholesky One S.D. Innovations ?2 S.E.

Response of SS to SS

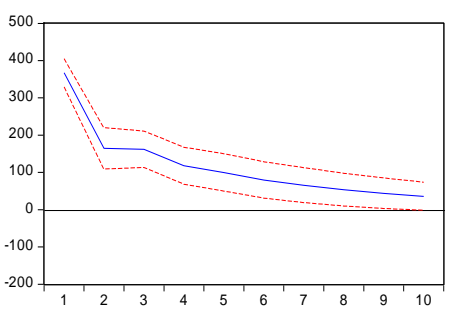

Response of R to SS

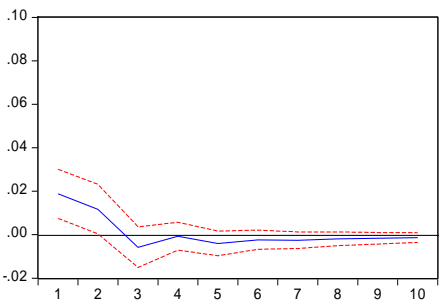

Response of SS to $\mathrm{R}$

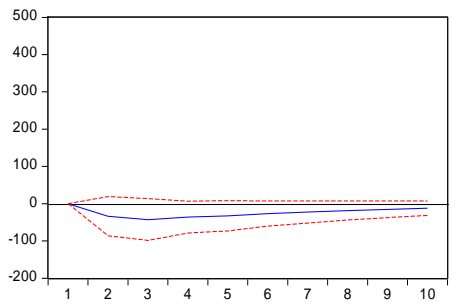

Response of $R$ to $R$

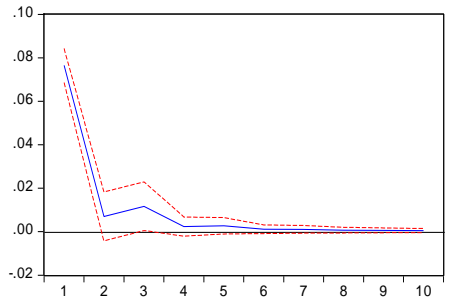

Figure 2. Pulse response of SS and R

\subsection{Variance Decomposition}

The impulse response function is to describe the impact of an endogenous variable in a VAR model on other endogenous variables. Variance decomposition is the analysis of the contribution of structural shocks that affect endogenous variables. In order to study how short-term international capital flows affect Chinese stock market, this paper analyzes the variance of the Shanghai composite index yield $\mathrm{R}$ to determine its source of variance.

It can be seen from Table 4 that $\mathrm{R}$ is predicted for the next 10 periods. Short-term international capital inflows contribute about 8 per cent of the Shanghai composite index yield. It can be seen that the Shanghai composite index yield is less affected by short-term international capital inflows. The Shanghai composite index yield is mainly affected by its own new information contribution. It shows that short-term international capital flows account for only a small part of the many factors influencing stock market returns.

Table 4. The contribution rate of SS to $\mathrm{R}$

\begin{tabular}{cccc}
\hline Period & S.E. & SS & R \\
\hline 1 & 0.078758 & 5.676803 & 94.32320 \\
2 & 0.079930 & 7.650378 & 92.34962 \\
3 & 0.080984 & 7.963421 & 92.03658 \\
4 & 0.081020 & 7.963671 & 92.03633 \\
5 & 0.081166 & 8.184179 & 91.81582 \\
6 & 0.081208 & 8.259403 & 91.74060 \\
7 & 0.081255 & 8.348786 & 91.65121 \\
8 & 0.081281 & 8.398567 & 91.60143 \\
9 & 0.081300 & 8.436791 & 91.56321 \\
10 & 0.081313 & 8.461152 & 91.53885 \\
\hline
\end{tabular}

\section{Conclusions and Suggestions}

Under the background of economic globalization, the development of the financial industry has also deepened, and the impact of international capital flows on the stock market in China has gradually increased. Normal international capital inflows will bring many benefits to emerging market countries, but large-scale frequent inflows and outflows may have negative effects on all aspects of emerging market countries. This article mainly studies the impact of short-term international capital flow on Chinese stock market. By defining the size of short-term international capital flows and describing the situation in Chinese stock market, under the sample of monthly data from 2002 to 2017, based on the empirical research of VAR model, Chinese short-term international capital flows have a direct impact on stock market returns. Initially, short-term international capital inflows will promote the rise of stock returns. After making profits, capital will be withdrawn quickly, causing a decline in the 
yield rate and increasing the volatility of the stock market.

According to the research conclusions, put forward the following suggestions. The first is to improve the international capital flow warning system, regularly reviewing international capital flows, preventing the rapid flow of hot money. As short-term international capital flows show the characteristics of speculation, their large-scale and frequent flows have a significant impact on a country's economy. Improving the early-warning mechanism of international capital flows can effectively avoid the formation of impact. Second, we will carefully open the capital account and effectively supervise the capital account. Too early and too fast liberalization of capital account may lead to a large inflow of international speculative capital, which will promote domestic asset prices. And these speculative capital will be pulled out quickly, and will increase the volatility of domestic asset prices. Third, strengthen the system construction of Chinese stock market and maintain the stability of the stock market. The imperfect financial system is not conducive to the long-term healthy and effective development of the stock market. It is necessary to carry out strict qualification examination and supervision and management of listed companies to ensure that the market can timely absorb adverse shocks and promote the healthy and stable development of Chinese stock market.

\section{Acknowledgments}

I am very grateful to Yanhu Gao, Xingyu Dai and Chao Chen for their help in the preliminary data enquiries, and for encouragement in the thesis writing.

\section{References}

Byrne, J. P., \& Fiess, N. (2016). International capital flows to emerging markets: national and global determinants. Journal of International Money \& Finance, 61, 82-100. https://doi.org/10.2469/dig.v46.n10.3

Chen, D. (2013). Empirical analysis of stock returns of banks in China's A-share markets. Social Science Electronic Publishing. https://doi.org/10.2139/ssrn.2324640

Diao, Y. (2015). Empirical study on stock return volatility in China's stock market. Journal of Investment Management, 4(5), 186. https://doi.org/10.11648/j.jim.20150405.17

Hui, M., \& Hui, X. F. (2011). Economic analysis and empirical study on factors affecting short-term capital flows of China. International Conference on Management Science and Engineering (pp. 1211-1217). https://doi.org/10.1109/icmse.2010.5719949

Jia, X., \& Ren, Y. (2017). The impact of institutional factors and capital market openness on short-term international capital flow. International Conference on Industrial Economics System and Industrial Security Engineering. https://doi.org/10.1109/ieis.2017.8078613

Lee, C. F., Chen, G., \& Rui, O. M. (2001). Stock returns and volatility on china's stock markets. Journal of Financial Research, 24(4), 523-543. https://doi.org/10.1111/j.1475-6803.2001.tb00829.x

Pan, W. (2010). Empirical analysis of stock returns volatility in China market based on Shanghai and Shenzhen 300 Index. International Conference on Financial Theory and Engineering (pp. 17-21). https://doi.org/10.1109/icfte.2010.5499433

Qi, L., Jian, Y., Cheng, H., \& Young-Jae, C. (2005). The relationship between stock returns and volatility in international stock markets. Journal of Empirical Finance, 12(5), 650-665. https://doi.org/10.1016/j.jempfin.2005.03.001

Rilina, B., \& Ranjanendra, N. N. (2011). Stock market, capital flow and output: Some analytical and policy perspectives. Macroeconomics \& Finance in Emerging Market Economies, 4(1), 85-99. https://doi.org/10.1080/17520843.2010.532145

Shi, G. (2014). The calculation of Chinese short-term international capital flow: Based on bop. International Journal of Economics \& Finance, 6(8). https://doi.org/10.5539/ijef.v6n8p103

Song, B., \& Gao, B. (2007). Impact of international capital flows on real estate market: the empirical test in china from 1998 to 2006. Frontiers of Economics in China, 2(4), 520-531. https://doi.org/10.1007/s11459-007-0027-8

Zhang, Y. (2018). Impact of short-term international capital flows on interactivity of stock market and real estate market in Chinese first-tier cities: A viewpoint of "co-selling effect". Journal of Financial Risk Management, 7(1), 1-11. https://doi.org/10.4236/jfrm.2018.71001 


\section{Copyrights}

Copyright for this article is retained by the author(s), with first publication rights granted to the journal.

This is an open-access article distributed under the terms and conditions of the Creative Commons Attribution license (http://creativecommons.org/licenses/by/4.0/). 